\title{
Multinationals in Europe 2001-2: home country, host country and sector effects in the context of crisis
}

\author{
Ian Clark, Trevor Colling, Phil \\ Almond, Paddy Gunnigle, Mike \\ Morley, Rene Peters and Marta \\ Portillo
}

\begin{abstract}
Introduction
In their review of multinational companies (MNCs) in this journal last year, our colleagues (Muller-Camen et al., 2001) explored the interaction of home and host country effects on subsidiary operations. They concluded that the location of MNCs in different national business systems provides variable attitudes towards employee relations. A large body of literature on US MNCs in Europe suggests that they seek to transfer practices from their home base and act as innovators in areas such as pay and work organization. These home country practices may challenge national systems of collective representation and bargaining (Almond, Edwards and Muller, 2001). Muller-Camen et al. (2001) temper this general conclusion by suggesting that national business systems, particularly components of the industrial relations system, exhibit extensive variation across the EU and remain a strong influence on the behaviour of MNCs.

In reviewing this past year, we are obliged to continue this line of analysis but also to extend it. Key consequences for multinational behaviour have been generated by two related events; developing economic recession, particularly in so far as it affected American markets, and the amplifying effect on this of the events of September 11 2001. Shock effects were felt first and most in two key internationalised
\end{abstract}

\footnotetext{
$\square$ Ian Clark, Trevor Colling, Phil Almond are Principal Lecturer, Senior Research Fellow and Research Fellow at Leicester Business School, De Montfort University; Paddy Gunnigle and Mike Morley are Professor of Business Studies and Senior Lecturer at the College of Business, University of Limerick; Rene Peters is Research Fellow at the University of Trier; and Marta Portillo is Lecturer at IESE Business School.
} 
sectors. Airlines were hit immediately by the temporary closure of American airspace and the medium-term impact on demand for transatlantic routes. Information technology companies have had to weather continued shifts in demand for their product, exacerbated by recession. Since news and business coverage for the year cohered substantially around these two areas, we adopt a similar focus. Doing so prompts us to add to the analytical themes of home and host country. To what extent has the subsequent restructuring within and between companies been sector specific? Under what circumstances do such sector effects become significant and how are they tempered by broader home and host country influences? These two industries offer interesting contrasts on questions of this kind; though both are now intrinsically transnational, they are structured quite differently. In terms of employment, airlines remain concentrated in their home countries but information technology, particularly the production of hardware has become much more dispersed.

The paper proceeds through two sections. The first reviews recent domestic industrial relations developments in three European countries that are likely to impact on MNCs. Thematically, this cursory review aims to draw out the potential destabilising effects of MNCs on national structures and systems-namely works council rights in Germany, non-unionism and rights to bargain legislation in Ireland and aspects of labour market reform in Spain. More substantively section two examines the issues of sector and sector effects on MNCs in the broader context of September 11, in particular its ramifications for industrial relations in civil aviation and information technology.

\section{Foreign direct investment, MNCs and contemporary industrial relations developments in Germany, Ireland and Spain}

\section{Germany-merger and acquisition activity and investment by MNCs}

The Mannesmann Vodafone merger provides an opportunity to review MNC activity in Germany in the context of emergent pressures to regulate cross border mergers and investment activity. In this context two major legal developments, which highlight the significance of the German industrial relations system are examined.

Cross border merger and acquisition activity has a major impact on industrial relations in several respects. Firstly, following on from the level of FDI or the number of employees in foreign-owned firms, merger and acquisition activity indicates the general influence of MNCs on an economy. Secondly, post-merger restructuring has social effects on employees, which, particularly in a phase of economic downturn are reflected in collective redundancies. The European Commission calculates that in 2001 merger and acquisition created 350,000 layoffs in Europe, (European Commission, 2002).

In July 2001 the European Parliament attempted to introduce an EU-wide directive to establish a well-regulated procedure for take-overs. This attempt failed in the main because of opposition from the German automobile and chemical sectors, (FAZ, 2001d). As a result of the EU's failure the German Parliament passed a national law that provides for mandatory regulation of take-overs. The legislation concedes more defensive measures to the Vorstand (board of directors) in the case of an attempted take-over.

A second legal development in 2001, which is expected to exert significant influence on German industrial relations, centres on legislation to reform the Betriebsverfassungsgesetz-the works constitution Act, an issue of great interest to foreign investors. This law has remained unchanged for thirty years but is now subject to several major reforms. The participation rights of works councils in areas such as environmental protection and racism are extended and the works council election procedure simplified. Finally, the law enables more works councillors to be freed from regular work per number of employees in a firm (EIRO, 2001a).

Among other lobby groups the American Chamber of Commerce-which with 3000 members is the largest bilateral economic federation in Europe-intervened in 
what was an intense dispute between trade unions and employer associations. Whilst the American Chamber of Commerce accepted that collective employee representation is a proven guarantor of social peace in the workplace criticism from its members was far reaching. Additional rights for works councillors will drive up costs and lead to greater bureaucracy affecting small to medium sized firms in particular. Moreover, the Chamber argued that national legislation of this type impairs the process of harmonization of business conditions across the EU (ACC, 2001). As a result of these concerns the American Chamber of Commerce predicts a decline in the propensity of MNCs to undertake FDI in Germany.

However, this position contrasts strongly with arguments put forward by Germany's minister for FDI, Hilmar Kopper who argues that in the first three months of 2001 FDI in Germany totalled $€ 43$ billion with the US leading the list followed by the UK, the Netherlands and France. Further, it appears that business leaders in US MNCs may hold different views on the attractiveness of Germany as a location for FDI than that formulated by the American Chamber of Commerce. For example, Aharon Mirsky, Motorola general Manager in Berlin argues that Germany is the place where decisions about technology are made' which go on to determine the wider European market (Handelsblatt, 2001). Other business leaders emphasise the strategic importance of Germany as a gateway to eastern European markets, particularly important with the prospect of further EU enlargement.

In summary the key issue that results from domestic legislation centres on its effects on FDI by MNCs and industrial relations in MNCs. Germany may be a higher labour cost economy than others and one where host regulation impairs the freedom of MNCs to act unilaterally. However, there is considerable empirical evidence to suggest that US MNCs in particular are prepared to trade-off higher labour costs in respect of higher productivity levels, that is, low labour costs are not necessarily the primary consideration in location decisions for FDI. Alternatively, the quality of the labour force that is available is a significant factor, (Ifo Institute, 1997; Cooke and Noble, 1998). Hence, whilst recent legislation in Germany may lead to better regulation of merger and acquisition activity and improve the position of works councils this may not deter FDI to any significant extent.

\section{Ireland-FDI, MNCs, and contemporary industrial relations}

Major economic, political and social changes characterise developments in the Irish economy in recent years. Considerable capital investment leading to sustained employment creation has combined with falling unemployment to result in an appreciable rise in the overall living standard. For much of the past decade Ireland was the OECD's fastest growing economy with GDP increases averaging 9\% per year since 1994. However, quarterly national accounts released in February 2002 reveal that GDP growth slowed to 3.2\% in the third quarter of 2001, (CSO, 2002). Ireland's long-term unemployment rate stands at $1.2 \%$ and a recent report predicts economic growth greater than the EU average but with slightly lower productivity which might see modest increases in unemployment, (Creation, 2002). Moreover, as wage increases are running ahead of productivity growth, competitive and productivity gains secured in recent years may be undermined (Sheehan, 2001). The manufacturing and service sectors has witnessed the bulk of economic and employment growth and Ireland is host to a significant number of foreign-owned companies who account for a considerable proportion of exports and employment. The trend over the past ten years shows that more jobs were created in foreign-owned firms than domestic firms, consequently, multinational investment combined with Ireland's approach to handling industrial relations are important in evaluating Ireland's recent economic performance.

Trends in FDI by MNCs in Ireland

Actively encouraging FDI by MNCs remains a key plank of Ireland's contemporary industrial policy. In a statement at the end of 2001, the Industrial Development Agen- 
cy's (IDA) head noted that the global slowdown in the information and communication technology sector had generated 'a small net loss' in IDA backed employment. However, the IDA expected to see a recovery in the course of 2002 and continues to compete strongly for investments in other growing sectors. Ireland continues to offer inward investors a package of financial incentives-most notably low levels of taxation on profits and a range of other attractions such as its young workforce $(47 \%$ of the population is aged under 29) and a comparatively unregulated industrial relations framework, (Gunnigle et al., 2002b). In following this approach Ireland is particularly successful in attracting FDI with the result that the economy is significantly more reliant on investment by MNCs than any other EU nation. Estimates suggest that FDI accounts for one third of the industrial workforce, 55\% of manufacturing output and 70\% of industrial exports, (Tansey, 1998). Further, a recent 62 nation study revealed that Ireland is now the world's most globalized economy, ranked well ahead of other countries considered to have open economies such as Singapore (3rd) and New Zealand (19th) (Brown, 2002).

There are 1,225 overseas firms operating in Ireland employing approximately 137,000 people with a particular focus on electronics, pharmaceuticals, software and internationally traded services. The main sources of FDI are the USA (42.3\%), Germany $(13.4 \%)$ and the UK (13.2\%) (IDA). OECD data reveal a threefold increase in FDI flows to Ireland since 1990, with the FDI by US MNCs now accounting for 85\% of all such inflows. The significance of US FDI was highlighted in the Economist's 1997 finding that almost 25\% of all US FDI in Europe-much of it non-union-is located in Ireland, while during the period 1980-1997 40\% of all new US FDI in the electronics sector went to Ireland, (OECD, 2000). Ramifications of restructuring in information technology are therefore particularly salient in Ireland and this is explored later.

\section{Contemporary industrial relations: union recognition and the right to bargain}

Industrial relations have played a significant role in the Irish success story. Since 1986 a series of centrally negotiated accords were agreed by the social partners (state, employers and trade unions). They represent the dominant feature in collective bargaining in Ireland in recent years, (D'Art and Turner, 2000). These agreements deal not only with pay, but also with a range of economic and social policy issues such as welfare provision, employment creation and tax reform. Each has given the Irish labour movement a pivotal role in shaping economic and social policy, see Gunnigle et al. (2002b).

Despite this role, union density in Ireland continues to decline. Trade union recognition now represents an area of significant debate, largely due to the fall in density since the early 1980's and concomitant rise in union avoidance strategies, particular among multinational firms.

While the decline in union density reflects the impact of several factors, it is clear that FDI has played a significant role. Current statistics indicate that density in 1999 was $44.5 \%$. This represents a fall of almost 10\% since 1994 in a period when employment has grown by a third, much of it in overseas, particularly US MNCs. In discerning the impact of FDI on union density, an important issue is the pattern of union recognition itself. A study of firms in the manufacturing and internationally traded services sector which covers green field sites over the period 1987-97 found a particularly high incidence of non-union firms. For example, over the whole period $80 \%$ of US firms are non-union whereas for firms locating during the period 1992$9791 \%$ are non-union compared to $54 \%$ for the previous five years. The majority of earlier period non-union firms were predominantly US owned firms in the information communication and technology sector. However, for the 1992-97 period the study found greater diffusion of union avoidance that embraces Irish and other European firms. Thus it appears that 'innovative' US human resource practice in nonunion firms broke new ground in this area and have encouraged a diffusion of new non-union managerial strategies to both new FDI investment and indigenous firms.

However, in the current period recent right to bargain legislation is an important 
development. Historically, the absence of a statutory mechanism for union recognition was less problematic than today as most employers tended to recognise and conclude collective bargaining agreements. The sharp falls in density described above-sustained and reinforced by FDI-prompted trade unions to seek a formal procedure to support recognition claims.

Under the framework of the centrally negotiated Partnership 2000 agreement a 'high level group on trade union recognition' was established to examine the issue. The group comprises government members, the Irish business and employers confederation, the IDA and the Irish congress of trade unions. The groups' initial report recommended the use of voluntary, as opposed to mandatory recognition procedures. However, a high profile dispute between Ryanair and SIPTU and the airline's refusal to concede recognition to baggage handlers resulted in broader trade union disaffection with the high level group report and its provisions relating to voluntary recognition procedures, (Gunnigle et al., 2002a,b). Amendments were subsequently made and a revised report issued in March 1999 culminating in the Industrial Relations (Amendment) Act in June 2001.

The high level group recommended a dual mechanism for dealing with disputes, namely a voluntary procedure on dispute resolution with a statutory fall back mechanism. The voluntary procedure became operative in 2000 by statutory instrument. In the event of negotiating arrangements failing to take place and the failure to move to collective bargaining the procedure details the process that should be put into place. This requires management and trade unions to co-operate in resolving the dispute.

The Act provides for statutory dispute resolution on this matter but fails to contain any provision for statutory union recognition. Here any determination issued by the Labour court cannot explicitly provide for collective bargaining arrangements and union recognition. Rather, the Act gives the Labour court the power, in particular circumstances, to make a binding determination on matters relating to terms and conditions of employment and procedures. The Act explicitly excludes any recommendation on collective bargaining arrangements. Non-union establishments who can demonstrate the presence of good conditions of employment and effective disputes procedures are effectively exempted for the legislation and investigation by the Labour court. In this way D'Art and Turner (2002) suggest that while in practice the legislation may improve employment relations practice and procedure it may also legitimise non-unionism.

The initial surge of FDI into Ireland in the 1980s appears indicative of theories that postulate a new international division of labour where MNC branch plants are attracted by readily available and comparatively cheap supplies of labour, (Henderson, 1989). This perspective sits uneasily with IDA claims that Ireland is, in some sectors, the high-technology centre of Europe, for example McGovern (1998) argues that there is some doubt on the R\&D capability of US MNCs in Ireland. However, evaluation of the IDA's efforts to encourage value-added production must be subject to continuing empirical research. Equally, the effects of Ireland's right to bargain legislation on trade union recognition appear strictly limited. As D'Art and Turner (2002) note, comparatively the Irish legislation is much weaker than Britain's recognition provisions. This suggests that its effects on the diffusion of non-unionism by US MNCs and its emergence as best practice for indigenous firms and MNCs from other countries of origin is open to doubt.

\section{Spain-FDI and pressures for reform of the labour market?}

2001 ended in Spain with signs of an economic downturn. International recession, before and after September 11 has clearly influenced policy makers in the country. In respect of its EU Presidency, in the latter part of 2001, the Spanish government stated its intention to open the energy and telecommunications sectors and reform the labour market across the EU (Lavin, 2002). FDI in Spain was 37\% lower in 2001 than in 2000, a reduction slightly less than UNCTAD's $40 \%$ estimate. Other EU 
nations accounted for $66 \%$ of FDI in 2001 with the UK emerging as the largest single investor contributing $18 \%$ of the total, the majority of which was in the telecommunications sector.

2001 was a particularly complex year in Spain in respect of industrial relations and labour market reform. The major reforms are highlighted below. Firstly, controversy over the high costs of dismissal was subject to dialogue between the Government and social partners, each of whom recognised that it has a significant impact on the country's comparatively high level of temporary employment (Eironline, 18-01-02,a). Secondly, for 2002, the national minimum wage (Salario Mínimo Interprofesional, SMI) will be increased by $2 \%$ taking into account the rate of inflation. The reaction of major trade unions to this was immediate, as they had been expecting an increase of around $7 \%$, a figure more in accordance with the criteria of reviewing the SMI as laid down in the scope of the Workers' Statute (Eironline, 18-1-02,b). Currently, Spain's SMI is one of the lowest minimum wage levels within the EU, barely above that of Portugal and Greece.

Thirdly, the Government, CC.OO (the major trade union) and the CEOE (the Spanish Confederation of Employers) signed an agreement culminating in the Flexible Retirement System Act which became law on January 1, 2002. This agreement aims to improve the national provision of pension payments by raising the retirement age. These measures have been taken to eradicate the increasing use of pre-retirements as a way of adjusting the workforce in companies (Expansión, 23-1-02; Eironline, 1801-02, c) and also aim to provide a mechanism for adjusting to emergent demographic changes in Spain, thereby meeting the labour force requirements of employers. For example, the government is currently working to modernise Vocational Training (VT). VT has always been considered by Spanish Society inferior to other forms of higher education. The reform proposals aim to re-orient and adapt VT initiatives to meet the needs of employers. Relatedly, in late 2001 and due to the on-going international economic crisis, the Spanish Government responded by urging employer organisations and trade unions to reach an agreement to reduce business cost and reform collective bargaining. On December 20, 2001, CEOE, CEPYME (Spanish Confederation of Medium and Small-sized Enterprises) and the two major Trade Unions, (C.OO and U.G.T) signed an agreement on wage moderation, measures to promote internal corporate flexibility, and improve conflict regulation.

Lastly, and perhaps the most significant issue during 2001 in Spain was the Fourth Labour Market Reform. The Spanish labour reforms between 1994 and 1997 aimed to loosen labour market regulation. In 2001, and looking forward to improving the 1997 labour reform agreement, labour authorities encouraged social actors to achieve new and voluntary agreements to enhance labour flexibility and stimulate job creation, particularly within multinational firms. However, the parties were unable to agree and the 2001 reform was imposed by a 'congressional decree' - a mechanism to push legislation through when a Government has a Parliamentary majority. The legislation aims to encourage permanent, long term and quality employment, to enhance part-time jobs - as a way to successfully fulfil the flexibility requirements of employers-and to guarantee transparency in the case of subcontracting.

In summary the material reviewed here accords with the conclusions of MullerCamen et al. (2001). For example, in Ireland country of origin practices associated with US MNCs such as non-unionism challenge national systems of collective representation and appear to be emerging as best practice for non-American firms. In Germany the continued centrality of national regulation on merger and acquisition activity and the regulatory capacity of works councils legislation illustrate how subsidiaries of MNCs remain subject to national regulation in host countries. In Spain the situation is similar although recent efforts by the Spanish state to loosen national patterns of regulation illustrate variation in the regulatory capacity of national business systems. This situation is mirrored in Ireland where efforts to re-regulate collective representation, contrast with Spanish strategies of de-regulation and are likely to have only a marginal impact on trade union density. To take the debate forward 
section two examines country of origin and host country effects in two specific sectors in the context of crisis and sector effects.

\section{Sectoral developments in civil aviation and information technology}

Civil aviation exhibits three broad sectoral characteristics that inform management strategy. First, the product is highly perishable-in crude economic terms the cost of an unsold seat is the same as one that is occupied but cannot be re-couped. Second, the sector is pro-cyclical, that is in periods of economic prosperity and boom the load factor (percentage of seats occupied) runs ahead of the average whereas in recession the load factor falls below the average. This is particularly important to airlines such as British Airways where transatlantic traffic is significant especially in business and first class bookings. Third, the reaction of multinational airlines to unforeseen events stimulates short-term responses that reinforce the first two characteristics. For example, the rapid downturn in economic activity in the US, the events of September 11 and prior to that the Gulf war and the success (higher load factors than MNC airlines) of low-cost airlines. The cumulative effect of the three characteristics is manifest in short-term pressures to reduce capacity-grounding aircraft, cutting the labour force and re-negotiating the pay-effort bargain-reducing hours and pay, initiatives that may already be in place-or at least strategised as part of longer term restructuring.

\section{Contrasting restructuring responses to September 11: BA, British Midland International (BMI), KLM and Lufthansa}

Taken together BA, BMI, KLM and Lufthansa reduced capacity by $13 \%$ since September 2001 (ILO, 2001). BA, BMI and KLM laid off over 10,000 workers or 10\% of their combined total workforce with BA recently announcing a further 6,000 redundancies as part of its 'Future Shape and Size' strategy, bringing total BA redundancies to 13,000 or $23 \%$ of its August 2001 workforce, (Financial Times, 14/2/02). In contrast to BA's announcement KLM's chief executive announced a noticeable improvement in the latter part of the last quarter of 2001 and suggested that KLM would raise capacity where prudent to do so and was unlikely to lay off more employees, (Financial Times 1/2/02). Equally, Lufthansa'a recent announcement of an expected $€ 400$ million operating profit this year indicate that the carrier has ridden out the short-term financial effects of September 11 which saw operating profits plummet to $€ 28$ million. Further the company is bringing 18 of the 43 aircraft it grounded in the wake of September 11 back into service (Financial Times, 29/6/02).

To reduce operating capacity and labour levels airlines deploy a variety of strategies. For capacity airlines terminate less or unprofitable routes, ground aircraft taking some out of service, cancel or waive options on new orders in favour of franchising aircraft, re-fitting existing units or retrieval of mothballed units. In terms of employment, airlines negotiate voluntary redundancies, announce compulsory redundancies, reduce wage levels and/or introduce two-tier wage levels or use cheaper overseas labour. Recent empirical work on civil aviation (Martinez Lucio et al., 2001; Turnbull et al., 2000) demonstrates that in the search to maintain competitiveness airlines are quite prepared to accept deterioration in established patterns of employment relations, Whilst in broad support of this finding Blyton et al. (2001) argues that trade unions are capable of engaging with restructuring to protect the interests of workers. However, one danger for employees who avoid redundancy is that the labour costs and standards associated with low-cost airlines may become the benchmark for larger carriers. British Airways is currently negotiating pay cuts for directors, senior managers and middle managers of between 5 and $15 \%$ and the cancellation of management bonuses throughout 2002. At BMI BALPA negotiated a $50 \%$ work and pay deal for all its pilots in an effort to reduce the impact of proposed 
redundancies of 109 pilots, $20 \%$ of its total number (ATI, 2001). Vereingigung Cockpit, the Lufthansa pilot's union has indicated its willingness to accept a $10 \%+$ pay cut to help restore profitability. In addition to this Lufthansa management have proposed a four-day week as a first measure to avoid staff redundancies.

In addition to the above measures there is speculation that BA is considering the launch of a low-cost airline. In BA's case this is remarkable due to its recent sell off of Go, and although Ron Eddington BA's CEO denies this the in-roads that low-cost airlines have made into BA's short haul routes is clearly evident in BA's recently announced 'Future Shape and Size Strategy'. BA aims to reduce in-flight service costs by using smaller aircraft and transfer some of its Gatwick operations to its low cost franchisee GB Airways. However, such a move is likely to provoke difficult employment relations issues and appears to contradict BA's previous branding strategyreflecting its failure- to target higher value business and first class loading. As Blyton et al. (2001) point out BA was successful in launching Go as a low-cost subsidiary, albeit an independent operator, primarily because Go negotiated a single union deal with the AEEU and operated a level of labour flexibility that reduced labour costs to around $80 \%$ of the BA standard. To negotiate similar cost-reductions for labour within BA may prove much more problematic. However, since BA's divestment of Go in 2001 the current BA strategy for short-haul routes clearly aims to benchmark low-cost carriers as the standard. Moreover, BA's efforts to reduce costs on short haul routes reflect wider difficulties in its globalization strategy such as a proposed take-over of KLM and a transatlantic alliance with American Airways. Both ambitions were recently frustrated by pronouncements made by EU courts that call into question the legality of bilateral -state-to-state agreements within the EU. A possible consequence of this is continued national re-structuring prior to EU-wider regulation and intra EU consolidation.

Relatedly, BMIs recently negotiated work-sharing agreement with its pilots, which aims to reduce cockpit crew job losses, is similar in substance to that negotiated by Lufthansa. BMI is $20 \%$ owned by Lufthansa and BMI is also a member of the multinational Star Alliance fronted by Lufthansa and a member of the Star Alliance European Works Council. The similarity of BMI's initial response, announcing 600 redundancies-9\% of its workforce, to BA's response does exhibit country of origin influences. However, the more measured response of negotiated work reductions perhaps shadows those of Lufthansa, suggesting a more co-ordinated response perhaps reflecting the growing significance of European Works Councils cutting across country of origin effects. In addition to this the launch of BMI's low cost carrier BMI Baby that aims to compete head on with Go and Easyjet on short haul routes illustrates the pervasive impact of the low cost standard.

\section{Corporatist reactions: Air France}

Air France dominates civil aviation in France, in which the state retains a majority shareholding. The business and industrial relations practices of Air France reveal a semi-detached relationship with global trends in civil aviation resulting in national patterns of regulation that appear to confirm existing observations on the nature of the French business system. On the one hand, the wider impact of sectoral business strategies is not unfamiliar. Air France is part of the Skyteam alliance, along with Delta, Alitalia, Korean Air, and Czech airlines. Equally, it has joined other major airlines in moving from a 'point to point' supply strategy to one based on the extensive use of its Paris hub, (Forbes Global, 2001). On the other hand, domestic features remain prevalent in the clear strategic importance of the airline to the state. This is reflected in the states relative lack of interest in acquisitive expansion abroad, and in the extent to which job security remains a significant constraint on management strategy, even after the floatation of the company. This latter factor is best illustrated by Air France's response to the decline in the air traffic following September 11. 
Specific response to September 11

$\mathrm{AF}^{\prime}$ 's response to September 11 was undoubtedly less severe for its employees than those of many other airlines. In the immediate aftermath, the company stopped new investment in planes, retired 18 aircraft, and announced a recruitment freeze. Further, an agreement to employ redundant staff from AOM-Air Liberté was put on hold.

While a French state-owned corporation, under a left-wing coalition continually having to attempt to demonstrate its virtues in the field of employment policy might be more likely than others to offer a relatively mild response to the crisis, contingent business factors were nevertheless at play. Firstly, Air France had achieved four straight years of profits from 1997 to 2000. Second, compared to other airlines, Air France is currently relatively cash rich, and, having largely avoided participation in the race to acquisitions of the 1990s, has relatively low debts. This of course does not immunise Air France from the medium-term re-structuring challenges that are likely to be posed if the market does not recover significantly, particularly as it retains one of the highest ratios of labour costs to revenue.

However, almost regardless of short-term business factors, it is probably true to argue that large-scale redundancies are politically unacceptable. Despite the fact that the airline is partially privatised, the political fallout from lay-offs would be considerable.

Given the fact that redundancies in profit-making firms remain deeply controversial in France (EIRO, 2002) reductions in the workforce as a response to a shortterm crisis would be unlikely, regardless of the political persuasion of the Minister of Transport.

The continuing near-monopoly of a state-owned flag carrier for international flights, benefiting from close links with the State and the civil service, means that the situation in France has perhaps changed less than elsewhere. Even with regard to internal flights, these factors, combined with a fast and reliable rail network within mainland France, have left the private sector at the margins and made the launch of French-owned budget airlines more difficult to achieve. In this area, at least, the French polity and the institutions of the national business system consolidate the notion of a single "national champion".

\section{Civil aviation in Spain: Iberia}

Iberia is the market leader in Spanish aviation and flies to 98 destinations in 39 countries. The company owns 200 planes and operates an average of 1,000 flights daily. It is also one of the most qualified companies in the aircraft maintenance industry and a member of the British Airways-American Airlines multinational 'Oneworld' alliance. Iberia has a 70\% market share in the Spanish market (Anonymous, 2001). Iberia is founder and part owner (27.92\%) of Amadeus, one of two computerised reservation systems in Europe with a world-wide prestige along with Lufthansa Commercial Holding (27.92\%) and Societe Air France (35.69\%). The company also owns Iberswiss, an airline catering Service Company, Cacesa, an 'overnight ' transportation company, and has stock in Tour Operators such as Viva Tours and Tiempo Libre.

After 11 September, the AECA (Asociación Española de Compañías Aéreas) ${ }^{1}$ predicted that Spanish airlines would suffer a reduction in earnings of $€ 240.40$ million and forecast layoffs of 15,000 workers unless the government provided financial relief (Candia, 2001). In summary, measures announced by Spanish airlines after the 11 September were as follows; Iberia reduced capacity by $11 \%$ (ILO,2001) and increased the tariffs by $€ 8$. Air Europa announced layoffs, reduced the number of flights and cancelled purchase orders for new planes. Air Nostrum showed least reaction merely

\footnotetext{
${ }^{1}$ The AECA is a non-profit industrial organisation, whose aims are the representation of private airline companies in Spain and the European Community. It includes all private companies in Spain except for Iberia.
} 
increasing tariffs by $€ 14,75$. Lastly, Spanair: reduced flights, but announced no layoffs, (El Mundo, 2001) Iberia's net profits on year end were $€ 50.2$ million, four times less than in the previous year (Expansión, 2002). However, Iberia's management remain and predict improved results in 2002 for the following reasons. First, the company is not the largest operator in the routes affected. Second, the experiences of Sabena and Swissair are unlikely, as Iberia's financial structure is sound. Third, Iberia has a stable workforce (since the last pilot's dispute agreement has been reached without any serious disagreement). However, whilst Iberia and other Spanish airlines appear less affected by recent events than other European airlines Iberia's situation must be placed in the wider context of globalization and intensified competition. Here the conclusions of Blyton et al. (1999), Turnbull et al. (2000) and Martinez Lucio et al. (2001) are instructive. Case study evidence on Iberia suggests that greater competition (from low-cost airlines and intensified global pressures) stimulates airline management into more assertive re-structuring strategies that erode 'traditional' terms and conditions of airline workers, often seeking to impose new operating procedures on the workforce. For example, in 1994 Iberia suffered strike action when it attempted to introduce both pay and job cuts. The evidence suggests that deterioration in management-labour relations and pay and terms and conditions of employment are an on-going process. For smaller Airlines the emergence of low-cost airlines is likely to consolidate and reinforce this process as the low-cost standard becomes the benchmark for European carriers on short-haul routes. It is unlikely that Iberia can buck this trend over the longer term, hence management labour relations will no doubt continue to deteriorate.

\section{Information technology}

In an annual review of this kind, attention to the information technology sector is justified by two reasons. First, is its continued high public policy profile. Generating core technology competencies and the stock of skills necessary for such a task have been preoccupations of government departments for some time. The Blair government has backed moves to develop a 'knowledge-based' economy in the UK and the Department of Trade and Industry has devoted time to organising conferences on the theme and resources to commissioned research and consultancy. In Spain too, the government developed Info XXI, an action plan that comprises 300 different initiatives and projects between 2001 and 2003, to implement an 'Information Society' for all the Spaniards. The prime emphasis being to increase the supply of skilled IT professionals. At European level, the European Commission launched a High-Level Task Force on Skills and Mobility in June 2001, with the aim of reducing barriers to labour market mobility across Europe. Focus again was provided by the supply-side needs of the 'new economy,' with particular analytical attention paid to the training and employment of IT professionals (EIROnline, 2001a). Yet 2001 provided a jolt for those depending predominantly on IT to rejuvenate employment and economies since business news coverage has been dominated by the radical restructuring initiated by IT companies, the second reason for their inclusion here. Taking these two factors together, we see an industry which is highly internationalised but which is structured in Europe now, unlike airlines, around a handful of key multinationals, most of them American.

At one level, recession was the primary cause of restructuring. Early in the year, industry specialists were warning that the rate at which IT investment is growing was likely to fall back, for the first time since the invention of the desktop computer. A survey of major US firms predicted growth at 8 per cent, rather than 11 per cent the previous year (The Observer, 8 April 2001). But this masks a deeper underlying crisis of manufacturing over-capacity. One reason for the favour heaped on the industry by policy makers now is that it was seen throughout the 1980s as recession-proof. Paradoxically, companies facing drops in revenue or profits pressures would invest large sums of money in IT systems, provided this enabled them to reduce adminis- 
tration or employment costs. IT systems underlay trends towards managerial delayering, for example. But hardware markets in particular have become saturated over time. Companies are less impressed with software innovation and the hardware used to run it has become more reliable. The importance of 2001, therefore, is that recession has compounded and accelerated changes in demand of a deeper nature. Companies have extended their replacement cycles from three years to four (The Observer, 11 November 2001) and the fall in hardware prices has increased to around 30 per cent per year (ibid.).

These underlying trends have impacted deeply on the configuration of the European IT industry, leaving it acutely vulnerable to crises of this sort. Archetypally, the sector developed through the 1970s on the basis of 'national champions.' Leading computing companies everywhere were linked closely with national governments, not least through the research and development support they received for military applications. In the US particularly, 'the electronic digital computer itself was created primarily for ballistics calculations and atom bomb analysis'. Leaps in British computing technology appeared more benign. (The Guardian, 6 May 2001). The world's first commercial IT applications were developed at Manchester and Cambridge Universities to track stock for Lyons, the catering company, in their famous Corner House Restaurants. Lyons themselves went on to manufacture further editions of LEO (Lyons Electronic Office) for commercial sale right up to the early 1960s when competition demanded the rationalisation of the eight computer manufacturers, under government guidance, to produce ICL. Similar processes were evident in France (Honeywell Bull) and Germany (Siemens).

Such policies have been largely abandoned in the 1980s and 1990s leaving Europe substantially dependent on foreign direct investment for its computing technologies. Much depends, of course, upon definitions of the sector and some exceptions remain. Ericsson is a market leader in communications technologies and has sustained considerable research and development in Sweden directly and by attracting collaborators, like IBM. In core areas of computing hardware and software, however, Europe does not perform well against the US and Japan. Britain is amongst the most computer-literate economies, recording relatively high measures on PC ownership, internet use, and employment in the industry. Yet critical weaknesses as a site of innovation have been noted. Levels of investment in innovation and research are low; the proportion of gross domestic product (GDP) spent on research and development (R\&D) declined through the $80 \mathrm{~s}$ and $90 \mathrm{~s}$. The City is seen as a major obstacle to innovation, making companies risk averse and focused on short-term market advantages to the detriment of medium term capacity building (ibid., 16). The UK and Germany were amongst the five OECD governments to have cut funding for R\&D during 90s (OECD, 2000: 5), the UK imposing the second most stringent reductions. Ireland increased government support and Spain topped the list in terms of increases to public funding, though from a relatively low-base (ibid.). Most European countries are below the OECD average when it comes to recording patents in ICT areas. Spain is the lowest of all, followed in ascending order by Germany, Ireland and then the UK. Consequently, most European countries are net importers of technology, with the exception of Belgium, the Netherlands and Sweden). The US is the main net exporter, followed by Japan.

The relative weakness of national champions in this context was highlighted strongly during 2001. Fujitsu, the Japanese hardware manufacturer, acquired ICL in 1992 since which point management in the subsidiary was focused on the objective of stock market flotation. Those plans were abandoned last year, followed closely by the resignation of ICL's Chief Executive, and the jettisoning of the ICL brand name (The Guardian, 22 June 2001). In France, the state continued to own 17 per cent of Bull (other significant shareholders include France Télécom, NEC and Motorola), and offered loans totalling $€ 150$ million to it in 2000 and 2001. Nevertheless, the group is currently undergoing a crisis that threatens its existence as an independent entity. In the last year Bull faced selling off large units of its business activity and the humiliation of selling its corporate headquarters in Paris. The company was split into two 
entities during 2000, one covering the servers business (Bull Infrastructure and Systems), the other covering its service activities (Integris). Yet by July 2001, the management had announced its intention to sell off most of the non-French activities of Integris to a smaller French firm Steria. This would leave Bull as a second-order manufacturer of servers, facing competition from such giants as IBM and Sun Microsystems.

The events of 2001 signal further important trends in terms of the kind of innovation stemming now from foreign direct investment in the IT area. Relying upon multinational companies to develop core technology competencies is an inherently risky business. Innovations in production techniques and product quality have positive ramifications for host countries, but the research and development upon which such advances depend takes place usually in the country of origin. Nearly half (40 per cent) of a representative sample of inward investors in the UK said that research and development accounted for less than 1 per cent of total costs, 60 per cent spent less than 2 per cent. One key explanation for this is the switch from manufacturing to services, a long-term trend amongst the major IT multinationals that accelerated in response to recession during 2001. The trend is most marked in the UK, a consequence of the importance of financial services to the economy (a big purchaser of IT services) and the large developing markets for IT contracts in the public sector. Of the OECD countries, the UK is the third largest employer of IT workers, after the US and Japan (Sharpe, undated: 1). Over half of those 1.11 million workers, though, are employed in computing services rather than research or manufacturing. Under Fujitsu's ownership, ICL stopped manufacturing hardware in 1996 but, in dropping the brand name last year, the position of the subsidiary as the European services wing of the corporation has been made clear. In Spain too, IT services grew by 21 per cent overall during 2001, twice the rate for hardware and for consumables (both around 10 per cent). Services now constitute half of the IT market and this proportion is increasing. Software, a small part of the Spanish domestic market relative to other European countries, has declined further from the peak associated with patches for Y2K problems. In France, both IBM and Hewlett Packard have sub-contracted their French PC manufacture to an American assembler, Sanmina SCI. This has also led to the restructuring of other areas of employment previously covered by the large IT firms; IBM for example, recently announced it was to stop the direct selling of PCs, with the activity once again sub-contracted. IBM's expansion in the UK during 2001, reportedly amounting to 2000 additional jobs, is focused exclusively in services which is said to constitute about 40 per cent of the company's turnover (The Guardian, 13 September 2001).

It is this rationalisation of manufacturing capacity that has propelled the IT multinationals into the headlines during 2001. Whilst some companies collapsed or suffered retrenchment, Gateway pulled out of manufacturing commitments in Ireland and the UK for example, others sought refuge in mergers and acquisition. Compaq sought merger with Hewlett Packard, much against the wishes of the latter's founding families who cited concerns about employee relations (The Observer, 17 March 2002). Seen within Compaq as aggressive horizontal integration enabling the company to compete head on with IBM, Hewlett-Packard opposed to the move on the grounds that it would diffuse the company's niche focus, on digital imaging, and require it to compete in the hugely risky PC markets. Any subsequent loss of margin would diminish the company's ability to maintain corporate values based on trust and employment security. Compaq had already announced employment cuts amounting to more than 10 per cent of the global workforce (The Guardian, 12 July 2001) and job loss was a marked feature across the industry during 2001.

As discussed above, Ireland's economic success in recent years was founded squarely on the use of tax and broader policy incentives to attract foreign direct investment, a strategy implemented with particular success in IT. Looking at the overall impact of the US downturn on the FDI sector in Ireland, we find the IDA end of year analysis showing a net loss of 3,800 jobs. This figure is comprised of job creation of 13,100 in the FDI sector, with concomitant job loss of 17,000 . Overall, this rep- 
resents a decline of $2.7 \%$ in employment, the first such decline in fifteen years (Dorgan, 2001). The information and communications technology (ICT) sector appears to have suffered most with employment down by $10 \%$ in the year. Industrial Relations News Reviews of Severance Settlements for 2000 and 2001 are instructive here. In their review of severance settlements in the electronics and information technology sector for 2000 there were six settlements with just over 1000 job losses in total. The 2001 review reveals 18 such severance settlements, covering over 3,600 employees (IRN, 2002). Prominent examples here have been the closure of Motorola's manufacturing plant in Dublin with a loss of 750 jobs and cutbacks at firms such as Gateway with the announcement in August 2001 that it was to close its European Headquarters in Dublin involving the loss of 900 jobs and a resultant drop of approximately $£ 600 \mathrm{~m}$ off Ireland's annual export total. This represents the largest single closure of an ICT company in Ireland in recent years. Significant also is the Intel announcement postponing its planned expansion at its Irish facility in Leixlip, Co Kildare, which would have created approximately 1,000 new jobs, along with the seeking of 170 redundancies. Dell, one of the few PC manufacturers to have sustained growth in 2001, increased employment in Ireland overall but this did not prevent severance for approximately 200 employees who were released as part of "an aggressive management of operating expenses" (Sheehan, 2001). The redundancies applied to middle management, non-production line supervisors and administrative supports.

Focus on the inward investors understates the full extent of job loss, which has also affected indigenous companies heavily focused on selling its products or services to either the US market or to US owned firms. The year 2001 witnessed a series of closures of Irish indigenous high tech firms, particularly in the software sectors, most notably Ebeon, Nua, Rondomondo, Viasec, Formus Broadband, Oniva and Breakaway Solutions while one of Ireland real stars in this sector, Baltimore Technologies, has been forced to severely cut back its activities.

In Spain, recent increases in IT employment started to freeze as employment in key areas was cutback. Hewlett-Packard illustrates the general trend. At the end of December 2001, the company was named leader in the Personal Computers industry in Spain for the eighth consecutive month, with a market share of 17.8\% (HP, 2001). The fiscal year also ended well for the company, with sales increasing 3.6 per cent on the year to E1,900 (HP (2), 2001). During the same year, HP opened new offices in Madrid, especially conceived for virtual jobs and to facilitate workers mobility (HP (3), 2001). It also inaugurated its 'Centre of Local Integration', which comprises the same production and laboratory characteristics of other European Integration Centres. Those Centres are called 'integrated' as they intend to unify the three steps of a product sale: conception, production and post sale service. At the same time, though, the company announced the closure of its Barcelona plant and the outsourcing of production, preferring to concentrate on higher value added business. The site had been seen previously as an important and innovative development; focusing R\& $\mathrm{D}$ and production of the company's large format printers in Spain contributed to employment growth from 35 employees to 1,500 over the 80s and 90s (EIROnline, 2001). The company offered paid-dismissals and/or outplacement.

It is difficult in a review of this kind to comment authoritatively on the nature of employment in those areas of the European IT industry that continues to thrive. The kind of evidence available, however, does not support adequately the association between information technology and increased skill-levels and 'employability' assumed often within policy discourses about the 'knowledge-based' economy. Employee development remains prominent in those companies able to defend dominant positions and operating in relatively regulated host-country environments. IBM was only slightly affected by the crisis in the IT sector in 2001 and so played a special role in the German IR system. IBM was among the first companies that signed a company-level agreement on employee development, which is regarded as a cornerstone of bargaining policy. An integral element of this contract is the right for each 
employee to discuss individual further training needs with supervisors once a year. ${ }^{2}$ But the IT workforce is hugely diverse but contains within it a large number of routine occupations. Tasks undertaken by computer programmers have been remodelled and fragmented so that the cache, creative elements now is undertaken by relatively few. For the rest, 'many computer workers possess but an aura of skill: their daily work is little more than specialized clerical labour'. The broader trends indicated here, particularly the growing importance in Europe of IT services, is suggestive of expansion in these kinds of areas overall rather than deep technological innovation taking place in innovation hubs, like Sweden. Possibly this explains the co-existence in countries like Spain of sustained recruitment difficulties and relatively low levels of pay. Overtures to staff adopted by many of the leading multinationals have tended to lean towards cost-control rather than more strategic orientations to skill and remuneration. In July 2001, for example, Hewlett Packard asked its employees worldwide to contribute to a global 'voluntary payroll savings programme' (EIROnline, 2001b). Staff were able to choose between one of four options: to accept a 10 per cent pay cut for four months; to accept a 5 per cent pay cut for four months and to renounce four days annual leave entitlement; to renounce eight days annual leave; or, finally, to agree to none of the other three options. The company declared the tactic a success, leading to savings of $\$ 130$ million over the financial year, but this did not prevent the subsequent announcement of 6,000 job losses, some 6.5 per cent of the workforce globally.

In contrast to airlines, restructuring of this kind faces relatively few obstacles in the IT industry since unionisation and joint regulation is limited relative to others. Amongst the IT companies investing in Ireland, union avoidance has become such a prominent feature that it is said to have contributed to the overall decline in union recognition in that country. Unions in Britain have had no influence over restructuring. Noting the disproportionate impact of Fujitsu's restructuring plans on the British workforce (cuts of 13 per cent were proposed for the UK, as against a 9 per cent global average), MSF was able only to complain about the relative ease with which employers in Britain can make workers redundant (The Guardian, 12 December 2001). In Spain too, workers in IT are not covered by the major sectoral agreements and collective bargaining remains relatively incipient, restricted to embryonic developments in limited areas, e.g., telemarketing. ${ }^{3}$ Unions opposing closures at Lucent and Hewlett-Packard have been able to ease the transition for workers but have not been able to prevent closures. Their complaints that Lucent's closure effectively ended the possibility of high-tech production in the region of Madrid proved ultimately to be futile (Expansión, 22-10-2001).

Even in Germany, sectoral collective agreements do not apply, either because IT companies are not members of the employers' associations or because they are covered by more flexible firm-level agreements bargained directly with the unions. Hewlett Packard has not been covered by any form of collective agreement since it left the employers' federation in 1974. This may be one factor explaining the relatively acquiescent response of $\mathrm{HP}^{\prime} \mathrm{s}$ German workforce to the cost saving described above. Despite opposition from IG Metall, emphasising the short-termist nature of HP's response, nearly 94 per cent of the 6,000 employees responded to the letter, the majority (80 per cent) agreeing to one or other of the cuts (EIRO, 2001b).

\footnotetext{
${ }^{2}$ A second important company agreement, though not in the IT sector, was concluded between the newly created union ver.di and Ranstad, the Dutch temporary employment agency. It applies to 21,000 employees and settles wage increases from May 2001. Even though it was expected that the agreement might act as a model for the whole temporary employment sector, changes in the Ministry of Labour's "Job-Aqtiv-Gesetz" reignited the old dispute around the question as to whether employees have to be paid according to the principles of the employment agency or its client (FAZ, 2001h).

${ }^{3}$ In June 2001 strikes and other industrial action in Spain's telemarketing sector took place. Trade unions sought the resumption of negotiations over a new national sectoral collective agreement and the introduction of improvements in pay and conditions. The action was well supported by the 40,000 workers in the sector, $90 \%$ of whom are employed under temporary contracts.
} 


\section{Conclusions: home country, host country, and sector effects in the context of crisis}

What then can the key developments of 2001-2 tell us about the behaviour of multinationals in Europe? Ambition in a review of this kind must be tailored to the kind of evidence available but some interesting themes for further research are apparent.

First, in both civil aviation and information technology pressures can be discerned that are sector specific. The shocks that September 112001 generated for airlines constitutes a sector effect so specific and extreme that it would be hard to replicate elsewhere. A vast and valuable airspace became inaccessible for nearly a week generating substantial loss of revenues and diminishing demand on transatlantic routes for the medium term. These shock effects established further pressures towards convergence in corporate strategies. One key development, common across carriers, is the rise to prominence of low-cost airlines and their role as a downward ratchet on terms and conditions of employment within 'core' businesses. Labour standards, ticketing and sales strategies and more selective routing in national carriers are benchmarking those of low-cost carriers. Here agreed patterns of job regulationworking practices, manning levels and employment levels appear as uncompetitive constraints as management introduce further rounds of low-cost inspired cost-cutting to raise productivity and compete more directly with low-cost carriers but more pertinently maintain shareholder value, (see Martinez et al., 2001).

Similar product related effects were apparent in information technology, where the novelty of declining demand for personal computers was exacerbated by recession during 2001. In the absence of product market regulation, as in civil aviation, the rationalising effects in most contexts were to practically eradicate the already weakened inclination to foster national champions, and to consolidate the position of a handful of US and Japanese multinationals. The drive towards 'knowledge-based' economies, of the kind favoured by European policy makers at national and EU level, is dependent to an overwhelming degree on the continued influx of foreign direct investment. Events during 2001, however, qualify the more optimistic expectations of enhanced employment prospects and skill development. Except for companies dominant in their sub-sector, Microsoft and Intel for example, the general trend in information technology was towards job reduction and the worsening of terms and conditions of employment. Obvious questions arise about such strategies in an industry that experiences recurrent problems with skill shortages. Explanations point first to the inherent irrationality of short-term responses to crisis in the context of weak regulation at sectoral level. IT companies operating in Europe tend not to participate in industry bargaining, even in relatively highly regulated economies like Germany. Where labour costs are not taken out of competition in this way, shortterm fluctuations in demand will be reflected in labour strategies. As important, and of deeper concern to policy makers, is the underlying shift towards investment in IT services and away from research and manufacturing. To the extent that 2001 accelerated such trends, the prospects for technology-driven recovery across Europe look bleaker than they did previously.

In both cases, however, sectoral responses were refracted to a significant degree by home and host country influences. Supposed 'deregulation' in civil aviation, both in the US and in Europe, is more accurately termed 're-regulation' (Martinez-Lucio et al., 2001). The year did witness some movement towards the kind of European integration that has long been predicted; the collapse of Sabena and Swiss Air arguably indicating the demise of national champions within the industry. Elsewhere, however, patterns of national and international regulation continued to permit government influence over their 'flag-carriers' and companies themselves to seek shelter. Job loss at Lufthansa and Air France were markedly less pronounced than in airlines relatively exposed to full commercial pressures, like British Airways.

The salience of host country environments, and their interaction with broader trends, is illustrated by developments in information technology. Differences between European states persist, in terms of their openness to FDI and the context 
in which it comes to operate. Ireland exemplifies an approach to capacity building in technology reliant substantially on overtures to multinational companies. The extent to which undoubted success enjoyed so far can be sustained in the light of international restructuring, and at what cost for patterns of domestic industrial relations, is but one of several interesting research questions for the future. By contrast, Sweden and Germany (to a lesser extent), have used investment in research and development, coupled with selective labour market reform, to develop 'technological hubs' around existing indigenous companies, like Ericsson for example. Configurations of this kind may prove more successful in attracting collaborative research and development and complex manufacturing capacity.

Variations between host-countries in labour market regulation have also mitigated to some extent the short-termist instincts of the IT multinationals. In France, for example, protective labour legislation, compulsory trade union recognition, and a wider societal antipathy to the announcement of redundancies among profit-making enterprises combined to make rationalisation a slower and more controversial process than in countries with more flexible labour markets, even if they did not combine to overcome wider sectoral trends completely. One significant brake on collective redundancies in the foreign-owned IT sector in France has been the fact that many such companies signed collective agreements in the late 1990s. These agreements, offered employment security, or at least a guarantee of total workforce size, in return for pay restraint in a sector with many skills shortages. Additionally, recently passed legislation prevents collective redundancies prior to negotiations on the 35-hour working week. Thus, Compaq's initial stated intention, when announcing global redundancy programmes in July 2001, was to divide the reduction of 830 jobs equally between Germany, France and the UK. But union representatives in France pointed to a collective agreement signed in 1999, guaranteeing a French workforce of 1,400. As the workforce had already declined below this number, and collective agreements have legal force, the unions were able to threaten the firm with civil court action. While the protection that this offer may not be long-term, the situation can be contrasted to the UK case, where a non-unionised workforce saw 800 jobs lost as a result of outsourcing to a Taiwanese firm operating in the Czech Republic (TGWU, 2001).

\section{Acknowledgements}

The authors acknowledge the help and provision of materials from John McGurk on the Airlines section and the useful advice provided by Mike Terry on the draft version of this article.

Corresponding author: Ian Clark, Leicester Business School, De Montfort University, The Gateway, Leicester LE19BH. iachum@dmu.ac.uk

\section{References}

Air Transport Intelligence, (2001).

Almond, P., T. Edwards and M. Muller, (with I. Clark, T. Colling, A. Ferner and L. Holden) (2001), 'The Embeddedness of US Multinationals in the US Business System: Implications for Employment Relations in the UK' paper presented at the European Industrial Relations Conference, Oslo, June, 25-29.

American Chamber of Commerce (2001), 'Zur geplanten Novellierung des Betriebsverfassungsgesetzes (BetrVG)', Position Paper, Frankfurt am Main.

Anonymous (2001), Iberia elige Broadvisión-Amadeus Travel Commerce para su nueva generación mundial de websites, 28-12-2001 at www.aui.es

Bispinck, R. (2001), 'Tarifpolitischer Halbjahresbericht: Eine Zwischenbilanz der Lohn- und Gehaltsrunde 2001', WSI Mitteilungen, 7, 419-425.

Blyton, P. and P. Turnbull (1996), 'Confusing Convergence: Industrial Relations in the European Airline industry-A Comment on Warhurst,' European Journal of Industrial Relations, 2, 1, 7-20.

Blyton, P., M. Martinez Lucio, J. McGurk and P. Turnbull (1999), 'Employment Relations Under DeRegulation: A Study of European Airlines, An End of Award Report' London, Leverhulme Trust. 
Blyton, P. Miguel Martinez Lucio, J. McGurk, P. Turnbull, (2001), 'Globalization and Trade Union Strategy: Industrial Restructuring and HRM in the International Civil Aviation Industry' International Journal of HRM May, 12, 3, pp. 445-463.

Brown, K. (2002), Ireland Heads World Index of Globalisation, Financial Times, Wednesday, January 9.

Bundesministerium fur Wirtschaft und Technologie (2002) 'Wirtschafsfckten Kommentiert' no. 1, Berlin

Candia, P. (2001), El sector de aviación español perderá 40.000 millones, El íaís, 20 de septiembre de 2001 at www.elpais.es.

Central Statistics Office (2002), Quarterly National Accounts: Third Quarter, 2001, Dublin: CSO.

Central Statistics Office (2002), Quarterly National Household Survey: Fourth Quarter, 2001, Dublin: CSO.

Cooke, W. and D. Noble, (1998), 'Industrial Relations Systems and US Foreign Direct Investment Abroad' British Journal of Industrial Relations 36, 4, pp. 581-611.

Cortés, (2002), Iberia Culmina su proceso de privatización con turbulencias, El íaís, 15 de febrero de 2002, Especial: Lo más relevante de 2001, at www.elpais.es.

Creaton, S. (2002), Irish Economy will outdo rest of EU: Report, Irish Times, March 4.

D'Art, D. and T. Turner, (2000), Social Partnership in Ireland: A View from Below, The Irish Journal of Management, 21, 151-169.

D'Art D. and T. Turner (2002), Union Growth and Recognition: The Irish Case in Comparative Context, Working Paper.

Directo, 12-12-01 at www.expansiondirecto.com

Dorgan (2001), A Year of Mixed Fortunes, IDA End of Year Statement, December 18.

Durán, F. (2001), El nuevo acuerdo de Seat: competitividad y flexibilidad, Expansión

Durán, F. (2002), Confianza en tiempos de crisis, Expansión Directo, 08-01-02 at www.expansiondirecto.com

The Economist (1997), The World's view of multinationals, The Economist, 354, 21-22.

Eironline (European Industrial Relations Observatory on-line) (20-11-2001) Dispute at Ford over new collective agreement, at www.eiro.eurofound.ie.

Eironline (European Industrial Relations Observatory on-line) (28-04-2001) Production ends at Hewlett Packard Barcelona, at www.eiro.eurofound.ie.

Eironline (European Industrial Relations Observatory on-line) (18-01-2002, a) Social Dialogue focuses on cost of dismissal, at www.eiro.eurofound.ie.

Eironline (European Industrial Relations Observatory on-line) (18-01-2002, b) Minimum wage increases by $2 \%$ in 2002, at www.eiro.eurofound.ie.

Eironline (European Industrial Relations Observatory on-line) (18-01-2002, c) Flexible Retirement System comes into force, at www.eiro.eurofound.ie.

Eironline (European Industrial Relations Observatory on-line) (13-12-2001) Agreement on workforce renewal and employment signed at Seat, at www.eiro.eurofound.ie.

Eironline (European Industrial Relations Observatory on-line) (25-10-2001) Impact of Opel restructuring plans in Spain at www.eiro.eurofound.ie.

Eironline (European Industrial Relations Observatory on-line) (20-12-2001) Redundancy procedure negotiated at Iberia, at www.eiro.eurofound.ie.

Eironline (European Industrial Relations Observatory on-line) (18-01-2002, d) Iberia redundancies approved, at www.eiro.eurofound.ie.

EIRO (2001a), 'Works Constitution Act reform adopted', EIRO observer, 6, 5-6.

EIRO (2001b), 'Employees accept pay cuts at Hewlett Packard', EIRO online, http: / / www.eiro.eurofound.ie/2001/08/InBrief/DE0108237N.html, 28 August.

EIRO (2001b, France) 'Employees back AOM-Air Liberte takeover' www.eurofound.ie

EIRO (2001c), 'Pilots and LTU airline agree rescue package', EIRO online, http: / / www.eiro.eurofound.ie/2001/11/Feature/DE0111207F.html, 20 November.

EIRO (2002), '2001 Annual Review of France' www.Eurofound.ie

EIRR (1993), 'IBM Goes it Alone', European Industrial Relations Review, 231, 16-18.

EIRR (2001), 'Agreement at Lufthansa', European Industrial Relations Review, 327, 8.

European Commission (2002), 'Commission calls the social partners for a dialogue on how to anticipate and manage the social effects of corporate restructuring', European Commission Press releases, IP/02/61, 15 January.

El Mundo (2001), Medidas anunciadas por las aerolíneas, El Mundo, 19 de septiembre de 2001, at www.elmundoviajes.es.

European Commision (2002), 'Commission calls the social partners for a dialogue on how to anticipate and manage the social effects of corporate restructuring'. European Commission Press Release, IP/02/61 January 15.

Expansión (24-10-2001), Gamesa Aeronáutica inicia el despido de 183 trabajadores, 
Expansión Directo at Expansión Directo at www.expansiondirecto.com

Expansión (22-10-2001), Lucent anuncia el cierre de su factoría de Tres Cantos,

Expansión Directo at www.expansiondirecto.com

Expansión (23-01-2002), Milonga de la jubilación flexible, Expansión Directo at www.expansiondirecto.com

Expansión (2002), El beneficio de explotación de Iberia cayó un 92\%, Expansión Directo, 25-012002, at www.expansiondirecto.com

FAZ (2001a), 'Preise für Unternehmen brechen ein', Frankfurter Allgemeine Zeitung, 28 December, 13.

FAZ (2001b), 'Schwedische Vattenfall siegt im Kampf um die Berliner Bewag', Frankfurter Allgemeine Zeitung, 4 December, 17.

FAZ (2001c), 'RWE ist größter Wasserversorger in Amerika - Rotkäppchen größter deutscher Sektanbieter', Frankfurter Allgemeine Zeitung, 28 December, 18.

FAZ (2001d), 'Die falsche Instanz', Frankfurter Allgemeine Zeitung, 9 November, 15.

FAZ (2001e), 'Keine Übernahmewelle durch steuerfreie Beteiligungsverkäufe', Frankfurter Allgemeine Zeitung, 13 November, 33.

FAZ (2001f), 'HP verlängert Frist für Abstimmung', Frankfurter Allgemeine Zeitung, 20 July, 16.

FAZ (2001g), 'HP muß 6000 Mitarbeiter entlassen', Frankfurter Allgemeine Zeitung, 27 July, 17.

FAZ (2001h), 'Die Zeitarbeit bleibt ein Zankapfel', Frankfurter Allgemeine Zeitung, 25 September, 17.

FAZ (2001i), 'Kritik begleitet Lufthansa-Schlichtung', Frankfurter Allgemeine Zeitung, 29 May, 19.

FAZ (2001j), 'Forster zum neuen Opel-Chef bestellt', Frankfurter Allgemeine Zeitung, 28 March, 30.

FAZ (2002a), 'Der Wert von Unternehmensübernahmen sinkt stark', Frankfurter Allgemeine Zeitung, 10 January, 12.

FAZ (2002b), 'Direktinvestitionen belegen Stärke', Frankfurter Allgemeine Zeitung, 17 January, 15.

FAZ (2002c), 'Opel streicht Gehalt und zieht Personalabbau vor', Frankfurter Allgemeine Zeitung, 11 January, 11.

Financial Times 'BA and KLM cut capacity' 23/1/02

Financial Times 'Complex EU legal net closes in on aviation deals' 1/2/02

Financial Times 'Eddington puts flesh to Size and Shape' 14/2/02

Financial Times 'Lufthansa Breaks Silence on Profit; 29/6/02

Forbes Global (2001), 'A Revamped Air France has emerged as one of the three leaders of the European airline industry, along with Lufthansa and British airways' www.forbes.com

Gunnigle, P., K. Murphy, J. Cleveland, N. Heraty and M. Morley (2002a), "Localization in Human Resource Management: Comparing American and European Multinational Corporations", Advances in International Management, (Forthcoming).

Gunnigle, P., M. O'Sullivan and M. Kinsella, (2002b), 'Organised Labour in the New Economy: Trade Unions and Public Policy in the Republic of Ireland', in D. D'Art, and T. Turner, (eds), Irish Employment Relations in the New Economy (Dublin: Blackhall Press, pp. 222-258).

Hall, P. and Soskice, (Eds) (2001) Varieties of Capitalism-The Institutional Foundations of Comparative Advantage (Oxford University Press).

Handelsblatt (2001), 'Trotz hoher Direktinvestitionen finden US-Firmen zunehmend Mängel am Standort Deutschland: Die zickige Braut', Handelsblatt, 27 August, 2.

Hanlon, J. (1996), Global Airlines: Competition in a Transnational Industry Oxford, ButterworthHeinemann.

Henderson, J. (1989), The Globalization of High Technology Production London, Routledge.

Higgins, C. (2001), SIPTU Conference: Recognition Rethink, Internal reorganisation, Industrial Relations News, October 11, pp. 19-20.

Higgins, C. (2001), The Right to Bargain Law: Is it Working?, Industrial Relations News, November 29 , pp. $20-26$.

Hollingsworth, JR., P. Schmitter and W. Streeck, (1994), 'Capitalism, Sectors, Institutions and Performance' in Hollingswork, Schmitter, and Streeck (Eds) Governing Capitalist Economies: Performance and Control of Economic Sectors, pp. 3-16. Oxford University Press

IATA (2000), World Air Transport Statistics.

Ifo Institute (1997), The EU Mechanical Industry: Monitoring the Evolution of Competitiveness. Munich.

ILO (2001), The Social Impact on Civil Aviation of events subsequent to 11 Septermber, 2001. ILO, Geneva.

IRN (2001), Nortel: Severance Deal Nears Completion, Industrial Relations News, October 25.

IRN (2002), Review of Severance Settlements: 2001, Industrial Relations News, February 21.

Kassin, H. (1997), 'Air Transport and Globalization: A Sceptical View' in Scott, A. (Ed) The Limits of Globalization. pp. 202-222, Routledge, London. 
Kriegbuam, A., A. Uhlig and H. Vieweg, (1997) EU Mechanical Engineering Industriy—Monitoring the Evolution of Competitiveness. Ifo Institute, Munich.

Lavín, R. R. (2002), España urge la liberalización de la energía, la telefonía y el mercado laboral de la UE, Expansión Directo, 08-01-02 at www.expansiondirecto.com.

Lehrer, M. (2001), 'Macro Varieties of Capitalism and Micro varieties of Strategic Management in European Airlines' in Hall and Soskice (Eds), pp. 337-361.

Martinez Lucio, M., P. Turnbull, P. Blyton and J. McGurk, (2001), ‘Using Regulation: An International Comparative Study of the Civil Aviation Industry in Britain and Spain' European Journal of Industrial Relations 7, 1, pp. 49-70.

M\&A International (2001), 'MEA Tranaktionsvolumen deutlich zurückgegangen-Zusammenwachsen der Old und New Economy', Press release.

McGovern, P. (1998), HRM, Technical Workers and the Multinational Corporation London, Routledge.

Muller-Camen, M., P. Almond, P. Gunnigle, J. Quintanilla and A. Tempel, (2001), 'Between home and host Country: Multinationals and employment relations in Europe' Industrial Relations Journal 32, 5, pp. 435-448.

OECD (2000), International Direct Investment Statististical Yearbook, Paris: OECD.

Romera, J. (2001), Alcampo desviará sus inversiones fuera de España por las restricciones, Expansión Directo, 23-10-01 at www.expansiondirecto.com.

Sheehan, B. (2001), Dell Pays Competitive Severance Package, Industrial Relations Newws, 21.

Sheehan, B. (2001), Ireland's Competitive Position Under Threat Says NCC, Industrial Relations News, October 25.

Tansey, P. (1998), Ireland At Work: Economic Growth and the Labour Market 1987-1997, Dublin: Oak Tree Press.

Turnbull, P., Blyton, P., McGurk, J., and Martinez Lucio (2000), 'Strategic Choice and Industrial Relations: A Case Study of British Airways', mimeo Cardiff Business School, Cardiff University.

Whitley, R. (2000), Divergvent Capitalism-The Social Structuring and Change of Business Systems. Oxford University Press. 